\title{
Efek motivational interviewing dan kelas edukasi gizi berbasis instagram terhadap perubahan pengetahuan healthy weight loss dan kualitas diet mahasiswi obesitas
}

Effect of motivational interviewing and nutrition education class based on instagram for change healthy weigh tloss knowledge and diet quality in obese female students

Ira Mulyani ${ }^{1}$, Fillah Fithra Dieny ${ }^{1}$, Ayu Rahadiyanti ${ }^{1,2}$, Deny Yudi Fitranti ${ }^{1,2}$, A Fahmy Arif Tsani ${ }^{1,2}$, Etisa Adi Murbawani $^{3}$

'Departemen Ilmu Gizi, Fakultas Kedokteran, Universitas Diponegoro, Semarang

${ }^{2}$ Center of Nutrition Research (CENURE), Fakultas Kedokteran, Universitas Diponegoro, Semarang

${ }^{3}$ Departemen Gizi Klinik, Fakultas Kedokteran, Universitas Diponegoro, Semarang

\begin{abstract}
Background: Obesity is a health problem that has a serious impact on women. Instagram is one of the media for nutrition education that can present healthy messages effectively and motivational interviewing can improves intrinsic motivation to changes in behavior. Objective: To analyze the effects of motivational interviewing and nutrition education class on changes in healthy weight loss knowledge and diet quality. Methods: This study used a quasi-experimental design with the pre-post test control group. The sample consists of 40 female students obesity were divided into three groups, control group (K); intervention group 1 with motivational interviewing and nutrition education class (P1); intervention group 2 only nutrition education class (P2). The nutrition education class based on instagram was given for thirty days and motivational interviewing was given 4 times with a duration of 15-45 minutes. Changes in healthy weight loss knowledge were assessed by pre-test and post-test questionnaire, while diet quality was assessed by Diet Quality Index-International (DQI-I). Results: There was a significant difference between healthy weight loss knowledge in the three groups. There were significant differences on sub-components of the adequacy of staple food ( $p=0.026)$, fiber $(p=0.026)$, protein $(p=0.006)$, total fat intake $(p=0.009)$, saturated fat intake $(p=0.024)$, sodium intake $(p=0.016)$, energy intake ( $(p=0.000)$, and carbohydrate intake $(p=0.002)$ in the three groups. Conclusions: Motivational interviewing and nutrition education class based on instagram could increase the healthy weight loss knowledge and reduce staple food intake, total fat intake, saturated fat intake, sodium intake, energy intake, and carbohydrate intake in obese women.
\end{abstract}

KEYWORDS: diet quality; education instagram; motivational interviewing; obese; weightloss knowledge

\begin{abstract}
ABSTRAK
Latar belakang: Obesitas merupakan masalah yang berdampak serius pada wanita. Instagram sebagai salah satu media edukasi gizi dapat menyampaikan pesan kesehatan secara efektif dan motivational interviewing dapat meningkatkan motivasi intrinsik untuk memperkuat perubahan perilaku. Tujuan: Penelitian ini bertujuan untuk menganalisis pengaruh motivational interviewing dan kelas edukasi gizi berbasis instagram terhadap perubahan pengetahuan healthy weight loss dan kualitas diet. Metode: Desain penelitian quasi-experimental dengan pre-post test control group. Subjek terdiri dari 40 mahasiswi obesitas yang dibagi menjadi kelompok kontrol (K); kelompok kelas edukasi gizi dan motivational interviewing (P1); dan kelompok kelas edukasi saja (P2). Edukasi melalui instagram diberikan selama 30 hari dan motivational interviewing diberikan 4 kali dengan durasi 15-45 menit. Perubahan pengetahuan healthy weight loss diukur dengan kuesioner pre-test dan post-test sedangkan perubahan kualitas diet diukur menggunakan instrumen Diet Quality Index-International (DQI-I) sebelum dan sesudah intervensi. Hasil: Terdapat perbedaan signifikan pada peningkatan pengetahuan healthy weight loss $(\mathrm{p}=0,001)$ di antara ketiga kelompok setelah intervensi. Terdapat
\end{abstract}

Korespondensi: Fillah Fithra Dieny, Departemen Ilmu Gizi, Fakultas Kedokteran, Universitas Diponegoro Semarang, Jl. Dr. Sutomo No.18, Semarang, Jawa Tengah, Indonesia,e-mail: fillahdieny@gmail.com

Cara sitasi: Mulyani I, Dieny FF, Rahadiyanti A, Fitranti DY, Tsani AFA, Murbawani EA. Efek motivational interviewing dan kelas edukasi gizi berbasis instagram terhadap perubahan pengetahuan healthy weight loss dan kualitas diet mahasiswi obesitas. Jurnal Gizi Klinik Indonesia. 2020;17(2):53-63. doi: 10.22146/ijcn.53042 
pula perbedaan signifikan pada kecukupan makanan pokok $(\mathrm{p}=0,026)$; kecukupan serat $(0,026)$; kecukupan protein $(\mathrm{p}=0,006)$; asupan total lemak $(p=0,009)$; asupan lemak jenuh $(p=0,024)$; asupan natrium $(p=0,016)$; asupan energi $(p=0,000)$; dan asupan karbohidrat $(\mathrm{p}=0,002)$ di antara ketiga kelompok. Simpulan: Motivational interviewing dan kelas edukasi gizi berbasis instagram dapat meningkatkan pengetahuan healthy weight loss dan menurunkan asupan makanan pokok, asupan total lemak, lemak jenuh, natrium serta asupan energi dan karbohidrat pada wanita usia subur obesitas.

KATA KUNCI: kualitas diet; edukasi instagram; motivational interviewing; obesitas; pengetahuan healthy weight loss

\section{PENDAHULUAN}

Obesitas didefinisikan sebagai suatu keadaan dengan akumulasi lemak tidak normal atau berlebihan yang dapat menggangu kesehatan (1). Studi terbaru melaporkan bahwa secara global, lebih dari 1,9 miliar orang dewasa kelebihan berat badan atau overweight dan 650 juta orang mengalami obesitas (2). Indonesia sebagai negara berkembang mempunyai risiko lebih besar menghadapi masalah obesitas $(3,4)$. Berdasarkan hasil Riset Kesehatan Dasar (Riskesdas) tahun 2018, tingkat obesitas pada orang dewasa di Indonesia meningkat dari 14,8\% pada tahun 2013 menjadi $21,8 \%$ pada tahun 2018 (5). Di Jawa Tengah, prevalensi obesitas mencapai 7,62\% dengan persentase laki-laki obesitas sekitar 6,4\% dan wanita obesitas 8,61\%(6). Angka tersebut sesuai dengan penelitian lain yang menyebutkan bahwa prevalensi obesitas lebih tinggi pada kalangan wanita dibandingkan laki-laki (2).

Obesitas merupakan salah satu faktor yang menyebabkan sebagian wanita sulit hamil (7). Status gizi pada wanita sebelum hamil atau masa prakonsepsi penting untuk diperhatikan (8). Wanita usia subur (WUS) adalah wanita pada masa prakonsepsi yang masih dalam usia reproduktif, yaitu antara usia 15-49 tahun dan masih berpotensi untuk mempunyai keturunan, termasuk didalamnya adalah kelompok mahasiswi. Wanita usia subur berperan sebagai windows opportunity dalam persiapan periode 1000 hari pertama kehidupan (HPK), yaitu masa awal kehidupan yang dimulai saat di dalam kandungan sampai 2 tahun pertama setelah kelahiran (9).

Salah satu penyebab obesitas pada WUS prakonsepsi yaitu kualitas diet individu yang rendah (10-12). Kualitas diet merupakan penilaian kualitas konsumsi makanan untuk mendeskripsikan seberapa baik diet seseorang berdasarkan rekomendasi diet. Idealnya, dengan kualitas diet yang baik, wanita mampu mencapai berat badan normal sebelum kehamilan untuk mengoptimalkan kesehatan ibu dan bayinya kelak (13).
Namun, ternyata banyak wanita yang mengalami berat badan berlebih hingga obesitas. Obesitas pada WUS berpotensi berlanjut menjadi obesitas saat kehamilan sehingga berisiko mengalami persalinan abnormal, abortus, dan komplikasi pascapersalinan (13). Selain itu, obesitas pada wanita juga dapat membentuk rantai obesitas dengan meningkatkan $40 \%$ risiko terjadinya obesitas pada anak yang dilahirkan (7). Dengan demikian, perlu adanya treatment obesitas pada wanita untuk mengurangi risiko tersebut.

Masa kehamilan bukan waktu yang tepat untuk treatment obesitas karena berpotensi membahayakan perkembangan janin sehingga penurunan berat badan pada WUS prakonsepsi penting dilakukan guna mengurangi risiko kesehatan yang mungkin terjadi serta mempersiapkan WUS dalam menghadapi periode 1000 HPK (13). Penanganan obesitas pada WUS adalah masalah multifaktoral yang membutuhkan tindakan dari individu obesitas itu sendiri. Masalah yang terjadi saat ini adalah banyak penderita obesitas yang belum berhasil menurunkan berat badan atau mempertahankan berat badan selama treatment obesitas $(7,14)$. Intervensi klinis dan farmakologis tidak cukup untuk mengatasi obesitas, perlu adanya perubahan perilaku dari individu itu sendiri (15).

Pengetahuan yang baik menjadi dasar perubahan perilaku atau kebiasaan seseorang. Edukasi adalah suatu metode serta upaya untuk meningkatkan pengetahuan sehingga perilaku seseorang berubah menjadi lebih baik (16). Banyak tantangan dalam penyampaian pesanpesan gizi pada mahasiswi sebagai generasi milenial yang berada dalam masa sibuk dan produktif. Media sosial instagram dengan jumlah pengguna di Indonesia mencapai 130 juta di tahun 2018 dapat menjadi salah satu terobosan baru untuk menyampaikan pesan atau informasi kesehatan (17). Studi menyebutkan bahwa pengetahuan saja tidak cukup untuk menjamin seseorang berperilaku sama seperti yang diketahui (18). Terdapat 
faktor lain yang turut mempengaruhi perubahan perilaku seseorang yaitu motivasi instrinsik. Penelitian menunjukkan bahwa banyak orang kelebihan berat badan atau obesitas mempunyai motivasi rendah untuk terlibat dalam keterampilan penurunan berat badan (14).

Terkait rendahnya motivasi perubahan perilaku pada wanita obesitas, beberapa penelitian telah menunjukkan bahwa penurunan berat badan yang efektif menggunakan program face-to face behavioral dengan pemberian dorongan dan konseling perubahan perilaku $(13,19)$. Motivational interviewing adalah gaya konseling yang telah terbukti berdampak pada modifikasi perilaku, termasuk diet dan aktivitas fisik (13). Penelitian sebelumnya menunjukkan bahwa kelompok yang diberikan intervensi edukasi dan motivational interviewing mengalami penurunan berat badan lebih tinggi dibandingkan dengan kelompok yang hanya mendapatkan intervensi edukasi (20). Namun, kekurangan dari penelitian tersebut adalah edukasi diberikan melalui pertemuan face to face sehingga subjek harus meluangkan banyak waktu dan membutuhkan tempat khusus untuk mendapatkan edukasi. Oleh karena itu, intervensi edukasi gizi dikembangkan menjadi edukasi berbasis media instagram yang dapat dijangkau oleh kalangan mahasiswi sebagai generasi milenial yang sangat aktif dalam penggunaan berbagai media sosial. Selain itu, pemberian intervensi edukasi gizi menggunakan media instagram belum pernah dilakukan pada penelitian sebelumnya. Berdasarkan latar belakang tersebut, penelitian ini bertujuan untuk menganalisis efek pemberian motivational interviewing dan kelas edukasi gizi melalui media instagram terhadap perubahan pengetahuan healthy weight loss dan kualitas diet pada mahasiswi obesitas.

\section{BAHAN DAN METODE}

\section{Desain dan subjek}

Desain penelitian ini menggunakan quasiexperimental with pre-post test control group design yang dilakukan di Universitas Diponegoro Semarang pada bulan Juli - Agustus 2019. Populasi target dalam penelitian ini adalah mahasiswi aktif Universitas Diponegoro sedangkan populasi terjangkau adalah mahasiswi aktif berusia 19-25 tahun dengan status gizi obesitas (IMT $>24,9 \mathrm{~kg} / \mathrm{m}^{2}$ ). Besar sampel minimal dihitung berdasarkan rumus peneltian analitik numerik tidak berpasangan sedangkan pemilihan sampel dilakukan secara proportional stratified random sampling.

Kriteria inklusi pada penelitian ini adalah subjek seorang mahasiswi aktif di Universitas Diponegoro; status gizi obesitas (IMT $>24,9 \mathrm{~kg} / \mathrm{m}^{2}$ ); berusia 19-23 tahun; belum menikah; tidak mengikuti program diet atau program penurunan berat badan dari pihak lain; aktif sebagai pengguna instagram dengan kriteria setiap hari aktif membuka instagram; dan bersedia mengikuti penelitian dengan mengisi formulir informed consent. Kriteria eksklusi pada penelitian ini yaitu mengundurkan diri menjadi subjek penelitian. Berdasarkan kriteria inklusi didapatkan jumlah subjek sebanyak 45 orang atau 15 orang per kelompok yang bersedia mengikuti rangkaian kegiatan penelitian.

Subjek dibagi ke dalam tiga kelompok secara acak, sebagai kelompok perlakuan pertama, kelompok perlakuan kedua, dan kelompok kontrol. Kelompok perlakuan pertama (P1) diberikan motivational interviewing dan kelas edukasi gizi berbasis instagram, kelompok perlakuan kedua (P2) diberikan kelas edukasi gizi berbasis instagram saja sedangkan kelompok kontrol (K) diberikan leaflet. Namun, dalam perjalanan penelitian sebanyak delapan orang sampel dropout karena data yang didapatkan kurang lengkap yaitu satu orang pada kelompok P1, dua orang pada kelompok P2, dan dua orang pada kelompok $\mathrm{K}$ sehingga sampel yang digunakan dalam penelitian ini yaitu empat belas orang kelompok perlakuan $1(\mathrm{P} 1)$, tiga belas orang kelompok perlakuan 2 (P2), dan tiga belas orang kelompok kontrol (K).

Outcome yang diteliti adalah pengetahuan healthy weight loss dan kualitas diet pada mahasiswi obesitas. Sebelum penelitian intervensi dilakukan, subjek diberikan sosialisasi penelitian dan pengarahan lebih lanjut secara terpisah pada masing masing kelompok. Pengarahan antara lain mengenai teknis dan aturan dalam pelaksanaan edukasi gizi menggunakan instagram, jadwal konseling (motivational interviewing), cara pengisian form food record setiap minggu yang meliputi jenis makanan, jumlah yang dikonsumsi berdasarkan ukuran rumah tangga (URT), waktu konsumsi, merk, dan lain lain. 


\section{Pengumpulan dan pengukuran data}

Variabel bebas adalah pemberian motivational interviewing dan kelas edukasi gizi berbasis sosial media instagram. Variabel terikat yang digunakan adalah pengetahuan healthy weight loss dan kualitas diet.

Kelas edukasi gizi berbasis instagram. Intervensi kelas edukasi gizi ini diberikan selama 30 hari dengan sistem one day one topic (satu hari satu topik) dan dilakukan secara tertutup yaitu hanya pada kelompok P1 dan P2 yang dapat menerima edukasi. Subjek yang dimasukkan dalam grup instagram hanya dari kelompok P1 dan P2. Materi edukasi berupa pengertian obesitas, cara pengukuran obesitas, anjuran asupan makan untuk obesitas, tips dan trik diet sehat, anjuran olahraga serta aktivitas fisik lainnya.

Motivational interviewing. Intervensi motivational interviewing adalah intervensi konseling gizi dengan strategi pemberian motivasi secara terus menerus kepada subjek kelompok P1. Pemberian motivational interviewing dilakukan sebanyak empat kali pertemuan dalam 1 bulan yaitu pertemuan tatap muka setiap satu minggu sekali dengan durasi 15-45 menit. Intervensi motivational interviewing dilakukan secara individual, yaitu satu orang subjek oleh seorang konselor yang tetap hingga akhir penelitian (20).

Pengetahuan healthy weight loss. Pengetahuan healthy weight loss merupakan pengetahuan tentang bagaimana cara menurunkan berat badan dengan benar dan sehat, perubahan pengetahuan diukur menggunakan kuesioner pre test dan post test berupa 20 pertanyaan mengenai healthy weight loss yang telah diuji validitas dan reliabilitasnya. Skor pengetahuan healthy weight loss dikategorikan menjadi pengetahuan baik (76-100\%), pengetahuan cukup (56-75\%), dan pengetahuan kurang $(<55 \%)(21)$.

Kualitas diet. Kualitas diet adalah penilaian kualitas konsumsi makanan untuk mendeskripsikan seberapa baik diet seseorang berdasarkan rekomendasi diet. Asupan makan sebelum intervensi diperoleh melalui tiga hari food record kemudian data asupan makan dilanjutkan dengan pengisian dua harifood record setiap minggu selama intervensi. Hasil dari food record yang telah dikumpulkan responden, divalidasi ulang oleh peneliti dengan menanyakan kembali kepada responden satu per satu menggunakan metode wawancara dan alat bantu buku foto makanan. Rerata asupan makan selama intervensi dibandingkan dengan rerata asupan makan sebelum intervensi. Perubahan kualitas diet responden diukur menggunakan formulir Diet Quality IndexInternational (DQI-I) yang menilai empat aspek dalam kualitas diet meliputi variasi (variation), kecukupan (adequacy), ukuran (moderation), dan keseimbangan keseluruhan (overall balance). Skor kualitas diet dikategorikan menjadi kualitas diet rendah $(\leq 60)$ dan kualitas diet tinggi ( $\geq 60)(22)$.

\section{Analisis data}

Analisis univariat dilakukan untuk menggambarkan variabel yang diteliti meliputi karakteristik subjek dan gambaran pengetahuan serta kualitas diet pada subjek sebelum intervensi. Normalitas data diuji dengan Saphiro Wilk. Perbedaan perubahan skor pengetahuan healthy weight loss dan kualitas diet pada ketiga kelompok dianalisis menggunakan One-Way ANOVA test dan Kruskall-Wallis test, kemudian dilakukan uji lanjut dengan menggunakan Mann-Whitney test. Penelitian ini telah mendapatkan ethical clearance dari Komite Etik Penelitian Fakultas Kedokteran Universitas Diponegoro/ RSUP Dr. Kariadi Semarang dengan No. 351/EC/KEPK/ FK-UNDIP/VII/2019.

\section{HASIL}

\section{Karakteristik subjek penelitian}

Sebagian besar subjek berasal dari jurusan saintek (70,3\%) dan bertempat tinggal di kos $(56,8 \%)$ dengan uang saku kurang dari Rp 800.000,- (Tabel 1). Hasil analisis pada Tabel 2 menunjukkan bahwa tidak ada perbedaan karakteristik, pengetahuan healthy weight loss pre, dan kualitas diet pre pada ketiga kelompok ( $\mathrm{p}>0,05)$. Hal ini menunjukkan bahwa penelitian ini dimulai dengan kondisi karakteristik subjek yang homogen.

\section{Gambaran pengetahuan dan kualitas diet sebelum intervensi}

Tabel 3 menunjukkan bahwa sebelum intervensi, mayoritas subjek belum mempunyai pengetahuan healthy weight loss yang baik. Hal tersebut ditunjukkan dengan 
Tabel 1. Karakteristik subjek penelitian

\begin{tabular}{|c|c|c|c|c|c|c|c|c|c|}
\hline \multirow[t]{2}{*}{ Karakteristik } & & \multicolumn{2}{|c|}{ P1 (n=14) } & \multicolumn{2}{|c|}{ P2 $(n=13)$} & \multicolumn{2}{|c|}{$K(n=10)$} & \multicolumn{2}{|c|}{ Total } \\
\hline & & n & $\%$ & $\mathbf{n}$ & $\%$ & $n$ & $\%$ & $\mathbf{n}$ & $\%$ \\
\hline \multirow[t]{2}{*}{ Jurusan } & Saintek & 9 & 64,3 & 10 & 76,9 & 7 & 70 & 26 & 70,3 \\
\hline & Soshum & 5 & 45,5 & 3 & 23,1 & 3 & 30 & 11 & 29,7 \\
\hline \multirow[t]{2}{*}{ Tempat tinggal } & Kos & 7 & 50,0 & 7 & 53,8 & 7 & 70 & 21 & 56,8 \\
\hline & Bersama keluarga & 7 & 50,0 & 6 & 46,2 & 3 & 30 & 16 & 43,2 \\
\hline \multirow[t]{3}{*}{ Uang saku } & $>\operatorname{Rp} 1.200 .000$ & 3 & 21,4 & 4 & 30,8 & 4 & 40 & 11 & 29,7 \\
\hline & Rp 800.000 - Rp 1.200 .000 & 6 & 42,9 & 4 & 30,8 & 2 & 20 & 12 & 32,4 \\
\hline & $<\operatorname{Rp} 800.000$ & 5 & 35,7 & 5 & 38,5 & 4 & 40 & 14 & 37,8 \\
\hline
\end{tabular}

$\mathrm{P} 1$ = kelompok perlakuan pertama (motivational interviewing dan kelas edukasi gizi berbasis instagram);

$\mathrm{P} 2=$ kelompok perlakuan kedua (kelas edukasi gizi berbasis instagram); $\mathrm{K}=$ kelompok kontrol (leaflet)

Tabel 2. Karakteristik subjek penelitian sebelum intervensi

\begin{tabular}{|c|c|c|c|c|}
\hline Karakteristik & $\begin{array}{r}\text { P1 (n=14) } \\
\text { Rerata } \pm \text { SD }\end{array}$ & $\begin{array}{r}\text { P2 }(n=13) \\
\text { Rerata } \pm \text { SD }\end{array}$ & $\begin{array}{r}\mathrm{K}(\mathrm{n}=\mathbf{1 0}) \\
\operatorname{Rerata} \pm \text { SD }\end{array}$ & $\mathbf{p}$ \\
\hline Usia (tahun) & $20,7 \pm 1,2$ & $19,6 \pm 0,7$ & $20,1 \pm 1,1$ & $0,085^{\mathrm{b}}$ \\
\hline Indeks massa tubuh $\left(\mathrm{kg} / \mathrm{m}^{2}\right)$ & $29,5 \pm 3,2$ & $27,5 \pm 1,2$ & $28,3 \pm 2,9$ & $0,179^{\mathrm{a}}$ \\
\hline Pengetahuan pre (\%) & $60,0 \pm 13,3$ & $55,0 \pm 12,4$ & $58,5 \pm 13,9$ & $0,633^{\mathrm{b}}$ \\
\hline Kualitas diet pre (skor) & $39,6 \pm 6,4$ & $38,3 \pm 5,1$ & $43,4 \pm 6,8$ & $0,193^{\mathrm{b}}$ \\
\hline
\end{tabular}

${ }^{\mathrm{a}}$ One-Way ANOVA test; ${ }^{\mathrm{b}}$ Kruskal Wallis test

persentase pengetahuan healthy weight loss subjek dengan kategori baik hanya 5,4\%. Persentase subjek sebelum intervensi pada beberapa kategori asupan makanan memperlihatkan adanya kebiasaan konsumsi makanan yang kurang baik pada WUS obesitas. Persentase yang tinggi pada subjek dengan kategori asupan lemak jenuh dan makanan rendah zat gizi yang berlebih menunjukkan bahwa WUS obesitas mengonsumsi makanan dengan zat gizi yang tidak seimbang, yaitu densitas zat gizi rendah dan tinggi lemak. Selain itu, subjek sebelum intervensi juga memiliki asupan sayur, buah, serat, zat besi, kalsium, dan vitamin $C$ yang kurang memenuhi kebutuhan seharihari. Namun, terdapat pula beberapa kategori asupan makan yang sudah memenuhi kebutuhan atau sudah baik, yaitu protein. Dengan demikian, diketahui bahwa secara keseluruhan mayoritas subjek sebelum intervensi memiliki kualitas diet rendah, artinya asupan makan harian kurang bervariasi dan berlebih sehingga tidak sesuai dengan gizi seimbang.

\section{Perubahan pengetahuan dan kualitas diet setelah intervensi}

Tabel 4 menunjukkan perubahan skor pengetahuan healthy weight loss yang signifikan $(\mathrm{p}<0,05)$. Setelah dilakukan uji lanjut Mann Whitney (Tabel 5), terdapat perbedaan antara kelompok P1 dengan kelompok K dan kelompok P2 dengan kelompok K. Rerata perubahan persentase skor pengetahuan pada kelompok P1 dan P2 meningkat, yaitu sebesar 17,8 $\pm 16,7$ dan $13,8 \pm 12,6$ sedangkan pada kelompok K menurun sebesar $-3,5 \pm 8,8$.

Kualitas diet terdiri dari empat komponen, yaitu variasi, kecukupan, moderasi, dan keseimbangan keseluruhan. Komponen kualitas diet yang menunjukkan perbedaan antar ketiga kelompok adalah komponen moderasi $(p=0,006)$ sedangkan komponen variasi, kecukupan, dan keseimbangan keseluruhan tidak menunjukkan perbedaan signifikan antar ketiga kelompok $(\mathrm{p}=0,735 ; \mathrm{p}=0,347 ; \mathrm{p}=0,394)$ (Tabel 4).

Komponen variasi dievaluasi dengan dua cara, yaitu secara keseluruhan dan berbagai jenis makanan yang termasuk dalam sumber protein dan kemudian digunakan untuk menilai apakah asupan berasal dari sumber yang berbeda. Hasil penelitian ini menunjukkan bahwa setelah intervensi, tidak ada perbedaan perubahan variasi secara keseluruhan maupun sumber protein antar ketiga kelompok $(\mathrm{p}=0,144 ; \mathrm{p}=0,058)$ karena pada ketiga kelompok mengalami perubahan variasi yang tidak jauh berbeda, baik secara keseluruhan maupun dari sumber protein. 
Tabel 3. Gambaran pengetahuan dan kualitas diet subjek sebelum intervensi

\begin{tabular}{|c|c|c|}
\hline Komponen & Kategori & n (\%) \\
\hline \multirow{3}{*}{$\begin{array}{l}\text { Pengetahuan healthy weight } \\
\text { loss }(\%)\end{array}$} & Baik (76-100) & $2(5,4)$ \\
\hline & Cukup (56-75) & $18(48,6)$ \\
\hline & Kurang $(<56)$ & $17(45,9)$ \\
\hline \multirow[t]{2}{*}{ Skor kualitas diet } & Tinggi $(>60)$ & $0(0)$ \\
\hline & Rendah $(\leq 60)$ & $37(100)$ \\
\hline \multirow{2}{*}{$\begin{array}{l}\text { Variasi kelompok makanan } \\
\text { (jenis/hari) }\end{array}$} & Baik $(\geq 3-5)$ & $16(43,2)$ \\
\hline & Kurang $(<3)$ & $21(56,8)$ \\
\hline \multirow{2}{*}{$\begin{array}{l}\text { Variasi sumber protein (jenis/ } \\
\text { hari) }\end{array}$} & Baik $(\geq 3-5)$ & $30(81,1)$ \\
\hline & Kurang $(<3)$ & $7(18,9)$ \\
\hline \multirow{3}{*}{$\begin{array}{l}\text { Kelompok sayuran (porsi/ } \\
\text { hari) }\end{array}$} & Baik $(\geq 3-5)$ & $0(0)$ \\
\hline & Cukup $(1,5-2,9)$ & $1(2,7)$ \\
\hline & Kurang $(<1,5)$ & $36(97,3)$ \\
\hline \multirow[t]{4}{*}{ Kelompok buah (porsi/hari) } & Lebih $(>3)$ & $3(8,1)$ \\
\hline & Baik $(\geq 2-3)$ & $2(5,4)$ \\
\hline & Cukup $(1-1,9)$ & $4(10,8)$ \\
\hline & Kurang $(<1)$ & $28(75,7)$ \\
\hline \multirow{3}{*}{$\begin{array}{l}\text { Kelompok makanan pokok } \\
\text { (porsi/hari) }\end{array}$} & Baik $(\geq 3-8)$ & $6(16,2)$ \\
\hline & Cukup $(1$, & $17(45,9)$ \\
\hline & Kurang $(<1,5)$ & $14(37,8)$ \\
\hline \multirow[t]{3}{*}{ Serat (gram/hari) } & Baik $(\geq 20-30)$ & $0(0)$ \\
\hline & Cukup (10-19) & $6(16,2)$ \\
\hline & Kurang $(<10)$ & $31(83,8)$ \\
\hline \multirow[t]{3}{*}{ Protein ( $\%$ energi/hari) } & Baik $(\geq 15)$ & $6(16,2)$ \\
\hline & Cukup (7,5-14) & $24(64,9)$ \\
\hline & Kurang $(<7,5)$ & $7(18,9)$ \\
\hline \multirow[t]{3}{*}{ Zat besi (\% AKG/hari) } & Baik $(\geq 100)$ & $0(0)$ \\
\hline & Cukup ( & $1(2,7)$ \\
\hline & Kurang $(<50)$ & $36(97,3)$ \\
\hline \multirow[t]{3}{*}{ Kalsium (\% AKG/ hari) } & Baik $(\geq 100)$ & $0(0)$ \\
\hline & Cukup (50-99) & $1(2,7)$ \\
\hline & Kurang $(<50)$ & $36(97,3)$ \\
\hline \multirow[t]{3}{*}{ Vitamin C (\% AKG/hari) } & Baik $(\geq 100)$ & $6(16,2)$ \\
\hline & Cukup (50-99) & $0(0)$ \\
\hline & Kurang $(<50)$ & $31(83,8)$ \\
\hline \multirow{2}{*}{$\begin{array}{l}\text { Total lemak ( } \% \text { total energi/ } \\
\text { hari) }\end{array}$} & Baik $(\leq 30)$ & $23(62,2)$ \\
\hline & Lebih $(>30)$ & $14(37,8)$ \\
\hline \multirow{2}{*}{$\begin{array}{l}\text { Lemak jenuh ( } \% \text { total energi/ } \\
\text { hari) }\end{array}$} & Baik $(\leq 10)$ & $13(35,1)$ \\
\hline & Lebih $(>10)$ & $24(64,9)$ \\
\hline \multirow[t]{2}{*}{ Kolesterol (mg/hari) } & Baik $(\leq 300)$ & $32(86,5)$ \\
\hline & Lebih $(>300)$ & $5(13,5)$ \\
\hline \multirow[t]{2}{*}{ Natrium (mg/hari) } & Baik $(\leq 2400)$ & $36(97,3)$ \\
\hline & Lebih $(>2400)$ & $1(2,7)$ \\
\hline \multirow{2}{*}{$\begin{array}{l}\text { Makanan rendah zat gizi } \\
(\% \text { energi/hari) }\end{array}$} & Baik $(\leq 10)$ & $1(2,7)$ \\
\hline & Lebih $(>10)$ & $36(97,3)$ \\
\hline
\end{tabular}

$\mathrm{AKG}=$ angka kecukupan gizi
Komponen kecukupan terdiri dari sub-komponen kelompok sayuran, buah, makanan pokok, serat, protein, besi, kalsium, dan vitamin C. Komponen ini mengevaluasi unsur-unsur asupan makanan yang seharusnya dikonsumsi dalam jumlah yang cukup. Hasil penelitian ini menunjukkan adanya perbedaan signifikan antar ketiga kelompok pada perubahan kecukupan makanan pokok, serat, dan protein $(\mathrm{p}=0,026 ; \mathrm{p}=0,026$; $\mathrm{p}=0,006)$. Berdasarkan uji lanjut, perubahan rerata kecukupan makanan pokok ditemukan antara kelompok P1 dengan kelompok K (Tabel 5), yaitu kelompok P1 mengalami penurunan rerata asupan makanan pokok sebesar $-0,6 \pm 1,2$. Penelitian ini juga menunjukkan perubahan rerata kecukupan serat dan protein antara kelompok P1 dengan P2, tetapi pada hasil tersebut justru pada kelompok P1 mengalami penurunan asupan serat dan protein $(-1 \pm 2,9 ;-1,2 \pm 4,8)$ sedangkan pada kelompok P2 meningkat.

Komponen moderasi mengevaluasi asupan makanan dan zat gizi yang berhubungan dengan penyakit kronis dan perlu dibatasi yang terdiri dari total lemak, lemak jenuh, kolesterol, natrium, dan makanan rendah zat gizi. Hasil penelitian ini menunjukkan adanya perbedaan antar ketiga kelompok pada sub-komponen total lemak, lemak jenuh, dan natrium ( $\mathrm{p}=0,009 ; \mathrm{p}=0,024 ; \mathrm{p}=0,016)$. Setelah dilakukan uji lanjut, perbedaan perubahan rerata asupan total lemak, lemak jenuh, dan natrium terjadi antara kelompok P1 dengan kelompok K, juga perbedaan perubahan asupan total lemak dan narium antara kelompok P1 dengan kelompok P2. Perbedaan tersebut karena terjadi penurunan rerata asupan total lemak $(-7,4 \pm 15,9)$, lemak jenuh $(-3,7 \pm 9,2)$, dan natrium $(-481,7 \pm 803,3)$ pada kelompok P1. Hasil analisis pada komponen ini menunjukkan bahwa penurunan komponen moderasi efektif pada kelompok P1.

Kategori terakhir yaitu keseimbangan keseluruhan merupakan kategori yang menganalisis keseimbangan keseluruhan diet dalam hal proporsionalitas antara sumber-sumber energi. Rasio makronutrien menunjukkan tidak ada perbedaan signifikan antar ketiga kelompok $(\mathrm{p}=0,394)$, tetapi terjadi perbedaan signifikan pada perubahan rerata asupan energi dan karbohidrat $(\mathrm{p}=0,000$; $\mathrm{p}=0,002)$. Berdasarkan uji lanjut, perubahan rerata asupan energi dan karbohidrat terjadi antara kelompok P1 
Tabel 4. Perubahan pengetahuan healthy weight loss dan kualitas diet berdasarkan komponen variasi, kecukupan, moderasi, dan keseimbangan keseluruhan

\begin{tabular}{|c|c|c|c|c|}
\hline \multirow{2}{*}{ Variabel } & \multicolumn{3}{|c|}{ Rerata \pm SD } & \multirow{2}{*}{ p } \\
\hline & P1 & $\mathbf{P 2}$ & $\mathbf{K}$ & \\
\hline$\Delta$ Pengetahuan healthy weight loss (\%) & $17,8 \pm 16,7$ & $13,8 \pm 12,6$ & $-3,5 \pm 8,8$ & $0,001^{b}$ \\
\hline$\Delta$ Skor kualitas diet & $-0,6 \pm 6,7$ & $0,1 \pm 8,6$ & $-4,2 \pm 9,6$ & $0,651^{b}$ \\
\hline$\Delta$ Skor variasi & $8,1 \pm 2,8$ & $8,8 \pm 2,4$ & $7,8 \pm 3,2$ & $0,735^{b}$ \\
\hline$\Delta$ Variasi kelompok makanan (jenis/hari) & $-0,2 \pm 1,1$ & $0,5 \pm 0,9$ & $0,6 \pm 1,1$ & $0,144^{\mathrm{b}}$ \\
\hline$\Delta$ Variasi sumber protein (jenis/hari) & $0,4 \pm 1,5$ & $-0,8 \pm 1,4$ & $0,4 \pm 1,01$ & $0,058^{\mathrm{b}}$ \\
\hline$\Delta$ Skor kecukupan & $-2,1 \pm 2,0$ & $-0,4 \pm 3,2$ & $0,4 \pm 5,2$ & $0,347^{b}$ \\
\hline$\Delta$ Kelompok sayuran (porsi/hari) & $0,02 \pm 0,3$ & $0,2 \pm 0,3$ & $0,3 \pm 0,6$ & $0,525^{b}$ \\
\hline$\Delta$ Kelompok buah (porsi/hari) & $-0,2 \pm 1,1$ & $0,1 \pm 1,4$ & $18,1 \pm 38,6$ & $0,355^{b}$ \\
\hline$\Delta$ Kelompok makanan pokok (porsi/hari) & $-0,6 \pm 1,2$ & $0,04 \pm 1,4$ & $1,1 \pm 1,9$ & $0,026^{b}$ \\
\hline$\Delta$ Serat (g/hari) & $-1,0 \pm 2,9$ & $2,2 \pm 2,1$ & $1,2 \pm 4,5$ & $0,026^{b}$ \\
\hline$\Delta$ Protein $(\%$ energi/hari) & $-1,2 \pm 4,8$ & $2,5 \pm 2,8$ & $4,7 \pm 4,22$ & $0,006^{b}$ \\
\hline$\Delta$ Zat besi (\% AKG/hari) & $-0,6 \pm 11,1$ & $5,2 \pm 8,8$ & $10,3 \pm 11,9$ & $0,204^{b}$ \\
\hline$\Delta$ Kalsium $(\% \mathrm{AKG} /$ hari $)$ & $-1,4 \pm 11,6$ & $3,6 \pm 10,7$ & $0,7 \pm 22,9$ & $0,532^{b}$ \\
\hline$\Delta$ Vitamin $\mathrm{C}(\% \mathrm{AKG} / \mathrm{hari})$ & $5,1 \pm 20,1$ & $17,2 \pm 29,8$ & $-24,1 \pm 115,3$ & $0,530^{\mathrm{b}}$ \\
\hline$\Delta$ Skor moderasi & $1,2 \pm 4,6$ & $-1,1 \pm 6,7$ & $-6,0 \pm 5,0$ & $0,006^{b}$ \\
\hline$\Delta$ Total lemak ( $\%$ total energi/hari) & $-7,4 \pm 15,9$ & $2,6 \pm 13,6$ & $9,5 \pm 9,5$ & $0,009^{b}$ \\
\hline$\Delta$ Lemak jenuh ( $\%$ total energi/hari) & $-3,7 \pm 9,2$ & $-2,2 \pm 8,7$ & $5,1 \pm 6,07$ & $0,024^{b}$ \\
\hline$\Delta$ Natrium (mg/hari) & $-481,7 \pm 803,3$ & $81,1 \pm 521,2$ & $197,8 \pm 458,5$ & $0,016^{b}$ \\
\hline$\Delta$ Kolesterol (mg/hari) & $-10,2 \pm 144,1$ & $27,3 \pm 125,5$ & $83,8 \pm 150,9$ & $0,433^{b}$ \\
\hline$\Delta$ Makanan rendah zat gizi $(\%$ total energi/hari) & $-0,7 \pm 16,4$ & $-17,9 \pm 17,7$ & $-7,5 \pm 14,9$ & $0,056^{\mathrm{b}}$ \\
\hline$\Delta$ Skor keseimbangan keseluruhan & $0,4 \pm 1,3$ & $0,3 \pm 1,7$ & $-0,4 \pm 1,2$ & $0,394^{\mathrm{a}}$ \\
\hline$\Delta$ Rasio makronutrien & $0,4 \pm 1,3$ & $0,3 \pm 1,7$ & $-0,4 \pm 1,2$ & $0,394^{\mathrm{a}}$ \\
\hline$\Delta$ Energi (kalori/hari) & $-322 \pm 346$ & $141,06 \pm 472$ & $498 \pm 378$ & $\mathbf{0 , 0 0 0 ^ { b }}$ \\
\hline$\Delta$ Karbohidrat (g/hari) & $-40,87 \pm 61,1$ & $-47,18 \pm 275,1$ & $498,8 \pm 378,6$ & $0,002^{b}$ \\
\hline
\end{tabular}

$\Delta=$ delta; $\mathrm{a}=$ uji One-Way ANOVA; $\mathrm{b}=$ uji Kruskal Wallis; P1 = kelompok motivational interviewing dan kelas edukasi gizi berbasis instagram; P2 = kelompok kelas edukasi gizi berbasis instagram; $\mathrm{K}=$ kelompok kontrol (leaflet)

Tabel 5. Perbedaan perubahan pengetahuan healthy weight loss dan kualitas diet antar kelompok

\begin{tabular}{lccc}
\hline \multirow{2}{*}{ Variabel } & P1-P2 & P1-K & P2-K \\
\cline { 2 - 4 } & $\mathbf{p}$ & $\mathbf{p}$ & $\mathbf{p}$ \\
\hline$\Delta$ Pengetahuan (\%) & 0,420 & $\mathbf{0 , 0 0 2}$ & $\mathbf{0 , 0 0 1}$ \\
$\begin{array}{l}\Delta \text { Kelompok makanan pokok } \\
\text { (porsi/hari) }\end{array}$ & 0,174 & $\mathbf{0 , 0 0 8}$ & 0,154 \\
$\Delta$ Serat (g/hari) & $\mathbf{0 , 0 0 7}$ & 0,095 & 0,687 \\
$\Delta$ Protein (\% total energi/hari) & $\mathbf{0 , 0 2 0}$ & $\mathbf{0 , 0 0 4}$ & 0,278 \\
$\Delta$ Moderasi (skor) & 0,108 & $\mathbf{0 , 0 0 2}$ & 0,087 \\
$\Delta$ Total lemak & $\mathbf{0 , 0 3 7}$ & $\mathbf{0 , 0 0 5}$ & 0,193 \\
(\% total energi/hari) & & & \\
$\Delta$ Lemak jenuh & 0,593 & $\mathbf{0 , 0 1 2}$ & $\mathbf{0 , 0 2 8}$ \\
(\% total energi/hari) & $\mathbf{0 , 0 2 6}$ & $\mathbf{0 , 0 1 2}$ & 0,385 \\
$\Delta$ Natrium (mg/hari) & $\mathbf{0 , 0 1 7}$ & $\mathbf{0 , 0 0 0}$ & 0,077 \\
$\Delta$ Energi (\% kebutuhan/ hari) & $\mathbf{0 , 0 4 3}$ & $\mathbf{0 , 0 0 0}$ & 0,186 \\
\hline Karbohidrat (\% kebutuhan/hari) & &
\end{tabular}

$\Delta=$ delta; nilai p dengan Uji Mann-Whitney; P1 = kelompok motivational interviewing dan kelas edukasi gizi berbasis instagram; P2 = kelompok kelas edukasi gizi berbasis instagram; $\mathrm{K}=$ kelompok kontrol (leaflet) dengan kelompok K dan kelompok P1 dengan kelompok P2. Penurunan rerata asupan energi $(-322 \pm 346)$ dan karbohidrat $(-40,87 \pm 61,1)$ terjadi pada kelompok P1. Hasil analisis ini menandakan bahwa penurunan asupan energi dan karbohidrat efektif pada kelompok P1.

\section{BAHASAN}

Karakteristik subjek, pengetahuan healthy weight loss pre, dan kualitas diet pre sebelum intervensi pada ketiga kelompok tidak berbeda signifikan $(p>0,05)$. Hal ini berarti karakteristik subjek antar ketiga kelompok sebelum intervensi adalah homogen. Sebagian besar subjek sebelum intervensi mempunyai pengetahuan healthy weight loss yang kurang. Namun, sesudah intervensi terdapat perbedaan perubahan rerata pengetahuan yang signifikan antar ketiga kelompok. Berdasarkan uji lanjut Mann-Whitney, perbedaan 
rerata pengetahuan terjadi antara kelompok P1 dengan kelompok kontrol dan kelompok P2 dengan kelompok kontrol. Perbedaan tersebut disebabkan peningkatan persentase skor pengetahuan healthy weight loss pada kelompok P1 dan P2. Berkaitan dengan hasil tersebut, pemilihan instagram sebagai media kelas edukasi gizi dinilai efektif untuk meningkatkan pengetahuan healthy weight loss pada mahasiswi obesitas sebagai generasi milenial. Instagram dipilih sebagai media penyampaian informasi karena mempunyai kelebihan, yaitu informasi yang disampaikan dapat disajikan lebih lengkap, dapat diterima kapan saja, informasi tidak hanya dalam bentuk teks melainkan dalam bentuk visual sehingga lebih menarik dan mudah dipahami, serta memungkinkan subjek menggali kembali informasi yang telah disampaikan dan bertanya apabila terdapat informasi yang kurang jelas. Hasil penelitian ini sejalan dengan penelitian sebelumnya bahwa peningkatan skor pengetahuan gizi lebih tinggi pada kelompok perlakuan edukasi berbasis internet dibandingkan kelompok kontrol (23).

Hasil penelitian ini juga menunjukkan bahwa peningkatan skor pada kelompok P1 lebih tinggi dibandingkan kelompok P2. Hal tersebut berarti intervensi edukasi berbasis media sosial instagram dan motivational interviewing jauh lebih efektif meningkatkan kognitif seseorang dibanding dengan intervensi edukasi dengan media sosial instagram saja. Berkaitan dengan hasil tersebut, dapat disimpulkan bahwa perlu adanya kombinasi antara media dan metode dalam penyampaian informasi sehingga hasil yang didapatkan jauh lebih efektif (24).

Gambaran kualitas diet sebelum intervensi menunjukkan bahwa mayoritas subjek mempunyai kualitas diet yang rendah. Hal tersebut disebabkan oleh asupan lemak jenuh pada komponen moderasi yang melebihi kebutuhan, rendahnya variasi jenis kelompok makanan pada komponen variasi, kurangnya sebagian besar zat gizi pada komponen kecukupan, dan rendahnya keseimbangan keseluruhan (makronutrien). Rendahnya variasi makanan pada subjek sebelum intervensi disebabkan subjek lebih memilih mengonsumsi kelompok makanan pokok dan kelompok makanan daging/unggas/ ayam/telur dengan pengolahan goreng tanpa diimbangi dengan konsumsi kelompok buah dan sayuran dalam jumlah yang cukup, sehingga mengakibatkan rendahnya beberapa asupan zat gizi seperti serat, besi, kalsium, dan vitamin C. Hal ini sejalan dengan penelitian yang menyatakan bahwa orang obesitas lebih suka mengonsumsi makanan yang tinggi energi, lemak, dan natrium, serta rendah vitamin dan mineral seperti fried chicken, french fries, beefsteak, dan pizza $(25,26)$.

Setelah intervensi, tidak terdapat perbedaan signifikan perubahan rerata skor kualitas diet pada ketiga kelompok. Sebelum dan sesudah intervensi, skor kualitas diet tetap dalam kategori rendah. Hal tersebut karena perubahan tidak terjadi pada semua komponen kualitas diet. Kualitas diet terdiri dari empat komponen utama, yaitu variasi, kecukupan, moderasi, dan keseimbangan keseluruhan (27). Hasil analisis perubahan rerata komponen variasi dan keseimbangan keseluruhan tidak menunjukkan perbedaan yang signifikan. Namun, perubahan rerata beberapa komponen kecukupan (makanan pokok, serat, dan protein); komponen moderasi (asupan total lemak, lemak jenuh, dan natrium); serta asupan energi dan karbohidrat menunjukkan perbedaan yang signifikan pada ketiga kelompok. Berdasarkan uji Mann-Whitney, terdapat perbedaan antara kelompok P1 dengan kelompok kontrol dan kelompok P1 dengan kelompok P2.

Kelompok P1 mengalami perbaikan pada asupan energi, karbohidrat, asupan makanan pokok, total lemak, lemak jenuh, dan natrium. Hal ini karena kelompok P1 memperoleh dorongan motivasi berulangulang disertai pendampingan melalui motivational interviewing sedangkan pada kelompok P2 dan kelompok $\mathrm{K}$ hanya memperoleh edukasi saja, tanpa motivational interviewing. Hasil ini didukung oleh penelitian yang menyebutkan bahwa konseling gizi, dalam hal ini adalah pemberian motivational interviewing, berperan terhadap kepatuhan diet. Motivational interviewing dapat menjalin pendekatan personal yang berguna untuk membantu individu memperoleh pengertian yang lebih baik mengenai permasalahan gizi yang dihadapi dan membantu untuk mengambil keputusan dalam mengatasi masalah gizi tersebut (28). Subjek dimotivasi untuk melakukan perbaikan perilaku yang berfokus pada pengurangan asupan energi, karbohidrat, dan lemak. 
Hasil ini juga sejalan dengan studi sebelumnya bahwa konseling dan edukasi berbasis komputer berdampak pada penurunan asupan lemak subjek (29).

Penurunan asupan makanan pokok pada kelompok P1 sejalan dengan penurunan asupan karbohidrat, mengingat makanan pokok seperti nasi, kentang, dan singkong merupakan sumber karbohidrat (9). Penurunan asupan energi pada kelompok P1 disebabkan berkurangnya asupan karbohidrat dan lemak. Setelah intervensi, diperoleh perbaikan pemilihan jenis makanan pada kelompok P1, yaitu subjek mengurangi sumber makanan tinggi lemak seperti gorengan dan fast food, serta mengurangi sumber makanan tinggi natrium seperti snack, mie instan, dan soft drink. Hal tersebut sejalan dengan penelitian tentang dampak pemberian edukasi dan motivasi pada remaja obesitas yang menunjukan penurunan asupan secara signifikan pada kelompok intervensi dengan penurunan konsumsi soft drink, mie instan, dan sandwich (30). Penurunan asupan protein pada kelompok P1 terjadi karena subjek mengurangi asupan fast food, seperti fried chicken, beef burger, dan ayam geprek yaitu makanan yang berbahan dasar daging atau ayam sehingga penurunan asupan lemak pada kelompok P1 bedampak pada penurunan asupan protein.

Berbeda dengan asupan karbohidrat dan lemak, peningkatan asupan serat dan protein terjadi pada kelompok P2 dan kelompok K dan sebaliknya pada kelompok P1 yang mengalami penurunan asupan serat dan protein. Penurunan asupan serat pada individu dapat disebabkan oleh beberapa faktor. Salah satu penyebab asupan serat rendah adalah individu tidak terbiasa mengonsumsi sumber makanan tinggi serat. Selain itu, ketidaksukaan individu terhadap sayur dan buah juga berdampak pada penurunan asupan serat (31). Subjek pada penelitian ini temasuk pada kelompok dewasa, yaitu kelompok kedua terbesar (96,9\%) yang kurang mengonsumsi sayur dan buah. Hasil studi menyebutkan bahwa walaupun hampir semua penduduk $(94,8 \%)$ mengonsumsi buah dan sayur setiap hari, tetapi konsumsi hanya dalam jumlah kecil yaitu 73,9 g/orang/hari (32). Berdasarkan Pedoman Umum Gizi Seimbang (PUGS), seorang dewasa dikatakan cukup konsumsi buah dan sayur jika mengonsumsi minimal $400 \mathrm{~g}$ sayur dan buah setiap hari (32). Rendah atau tingginya asupan serat juga dipengaruhi oleh ketersediaan sumber makanan itu sendiri (33). Makanan yang disediakan di lingkungan sekitar subjek, yaitu di kantin kampus dan tempat tinggal di rumah atau kos, cenderung tinggi energi tetapi rendah serat.

Pemberian intervensi motivational interviewing dan kelas edukasi selama 30 hari mampu memperbaiki asupan energi dan karbohidrat serta komponen moderasi (total lemak, lemak jenuh, dan natrium), tetapi belum efektif untuk memperbaiki asupan serat dan protein. Penelitian lain menyebutkan bahwa pemberian edukasi dan motivasi dapat meningkatkan asupan sayur dan buah dengan lama pemberian intervensi selama satu tahun (29).

Menurut Lawrence Green, perilaku individu dipengaruhi oleh tiga faktor antara lain faktor pendorong (predisposingfactors), faktor pemungkin (enablingfactors), dan faktor penguat (reinforsing factors) (34). Faktor pendorong merupakan faktor-faktor yang mempermudah terbentuknya perilaku individu (34). Faktor ini diantaranya pengetahuan. Tingkat pengetahuan dan sikap subjek membentuk suatu kebiasaan, dalam hal ini adalah perubahan asupan makan yang dapat mempengaruhi kualitas diet.

Faktor pemungkin merupakan hal-hal yang memungkinkan atau memfasilitasi terbentuknya suatu perilaku atau tindakan (34). Hal yang termasuk dalam faktor pemungkin adalah sarana dan prasarana terbentuknya suatu perilaku. Pada penelitian ini, faktor pemungkin terbentuknya perilaku adalah sarana berupa edukasi melalui media sosial instagram mengenai diet sehat pada wanita obesitas. Edukasi melalui media sosial instagram bertujuan untuk meningkatkan pengetahuan kemudian peningkatan pengetahuan tersebut akan membentuk suatu sikap baru terhadap suatu permasalahan. Tahap praktik berada pada tahap lanjutan ketika seseorang telah memiliki cukup pengetahuan dan sikap, serta komitmen atau motivasi untuk merubah perilaku. Sementara faktor pembentuk perilaku yang ketiga adalah faktor penguat, yaitu faktor-faktor yang mendorong atau memperkuat terbentuknya perilaku atau tindakan yaitu adanya dukungan dari tokoh yang berpengaruh (34).

Setelah diberikan edukasi melalui media sosial instagram, diketahui bahwa terjadi peningkatan pengetahuan pada kelompok perlakuan. Selain itu, subjek juga diberikan motivational interviewing sebanyak empat kali oleh profesional, hal ini dalam teori green termasuk faktor penguat (34). Pada tahap ini, subjek 
diberikan motivasi untuk mengubah perilaku khsususnya terkait perilaku makan pada obesitas. Setelah diberikan edukasi dan motivational interviewing, diketahui bahwa terjadi perbaikan komponen moderasi yaitu penurunan asupan total lemak, lemak jenuh, dan natrium serta pada sub-komponen asupan energi dan karbohidrat. Namun, perubahan tidak terjadi pada komponen variasi dan kecukupan karena terdapat faktor lain yang turut mempengaruhi seperti ketersediaan bahan pangan, sosial ekonomi/uang saku, serta preferensi atau kesukaan terhadap suatu bahan makanan (35).

Motivasi adalah kondisi kesiapan atau keinginan untuk berubah. Motivational interveiwing bertujuan untuk mengidentifikasi dan mengubah perilaku. Motivational interveiwing merupakan suportive talk therapy yang sederhana dan transparan berdasarkan pada prinsip-prinsip cognitive-behavioural therapy. Prinsip-prinsip tersebut untuk membantu seseorang dalam memahami proses pemikirannya terkait dengan masalah yang dihadapi, mengidentifikasi, dan mengukur reaksi emosional terhadap masalah, mengidentifikasi bagaimana pikiran dan perasaan berinteraksi untuk menghasilkan pola dalam perilaku, menantang pola pikir, dan menerapkan perilaku alternatif. Motivational interviewing berdasarkan landasan teoritis dari model Transtheoretical, yang lebih dikenal sebagai Stages of Change Model, yang dikembangkan oleh Prochaska dan DiClemente. Model tersebut menjelaskan perubahan perilaku pada seseorang terjadi melalui beberapa tahapan yaitu prakontemplasi-kontemplasi-perencanaan-tindakanfase pemeliharaan. Strategi motivasi mencakup delapan komponen yang dirancang untuk meningkatkan motivasi yang dimiliki seseorang hingga mengubah perilaku tertentu. Komponen-komponen ini meliputi memberi saran, menghilangkan hambatan, memberikan pilihan, mengurangi keinginan yang berlebihan tetapi kurang realistis, memberi empati, memberi umpan balik, dan mengklarifikasi tujuan agar dapat dicapai (36).

\section{SIMPULAN DAN SARAN}

Motivational interviewing dan kelas edukasi gizi berbasis instagram dapat meningkatkan pengetahuan healthy weight loss dan menurunkan asupan energi, karbohidrat, asupan makanan pokok, total lemak, lemak jenuh serta asupan natrium pada wanita usia subur obesitas. Saran untuk penelitian selanjutnya yaitu frekuensi motivational interviewing dan kelas edukasi gizi diberikan dalam waktu yang lebih lama, yaitu lebih dari dua bulan sehingga dapat membantu wanita usia subur obesitas untuk meningkatkan semua komponen kualitas diet.

\section{UCAPAN TERIMA KASIH}

Penelitian ini didanai oleh Hibah Riset Pengembangan dan Penerapan (RPP), Universitas Diponegoro tahun 2019.

\section{Pernyataan konflik kepentingan}

Penulis menyatakan tidak ada konflik kepentingan dalam penelitian ini.

\section{RUJUKAN}

1. Muller M, Geisler C. Defining obesity as a disease. Eur J Clin Nutr. 2017;71(11):1256-8. doi: 10.1038/ejen.2017.155

2. Katulanda P, Jayawardena MAR, Sheriff MHR, Constantine GR, Matthews DR. Prevalence of overweight and obesity in Sri Lankan adults. Obes Rev. 2010;11(11):751-6. doi: 10.1111/j.1467-789X.2010.00746.x

3. Ahirwar R, Mondal PR. Prevalence of obesity in India: a systematic review. Diabetes Metab Syndr. 2019;13(1):318-21. doi: 10.1016/j.dsx.2018.08.032

4. Dag ZO, Dilbaz B. Impact of obesity on infertility in women. J Turk Ger Gynecol Assoc. 2015;16(2):111-7. doi: 10.5152/ jtgga.2015.15232

5. Kementrian Kesehatan RI. Hasil utama riset kesehatan dasar (Riskesdas) tahun 2018. Jakarta: Badan Penelitian dan Pengembangan Kesehatan; 2018.

6. Dinas Kesehatan Provinsi Jawa Tengah. Profil kesehatan Provinsi Jawa Tengah. Semarang: Dinkes Jateng; 2016.

7. Anggraini S, Hasan Z, Afrida A. Pengaruh obesitas terhadap infertilitas pada wanita pasangan usia subur di Rumah Sakit Awal Bros Pekanbaru. Jurnal Proteksi Kesehatan. 2015;4(1):49-58.

8. Adinma J, Umeononihu OS, Umeh MN. Adolescent and pre-pregnancy nutrition in Nigeria. Trop J Obstet Gynaecol 2017;34(1):1-5.

9. Dieny FF, Rahadiyanti A, Kurniawati DM. Gizi prakonsepsi. Jakarta: Bumi Medika; 2019.

10. Crovetto M, Valladares M, Espinoza V, Mena F, Oñate G, Fernandez M, et al. Effect of healthy and unhealthy habits on obesity: a multicentric study. Nutrition. 2018;54:7-11. doi: 10.1016/j.nut.2018.02.003 
11. Lim J, Park HS. Trends in the prevalence of underweight, obesity, abdominal obesity and their related lifestyle factors in Korean young adults, 1998-2012. Obes Res Clin Pract. 2018;12(4):358-64. doi: 10.1016/j.orcp.2017.04.004

12. Hill JO, Wyatt HR, Peters JC. Energy balance and obesity. Circulation. 2012;126(1):126-32. doi: 10.1161/ CIRCULATIONAHA.111.087213

13. Dolin CD, Kominiarek MA. Pregnancy in women with obesity. Obstet Gynecol Clin North Am. 2018;45(2):217-32. doi: 10.1016/j.ogc.2018.01.005

14. Freira S, Fonseca H, Williams G, Ribeiro M, Pena F, Machado C, et al. Quality-of-life outcomes of a weight management program for adolescents based on motivational interviewing. Patient Educ Couns. 2019;102(4):718-25. doi: 10.1016/j. pec.2018.11.011

15. Zeidi IM, Hajiagha AP. Effect of motivational interviewing on eating habits and weight losing among obese and overweight women. J Obes Weight Loss Ther. 2013;3:172. doi: 10.4172/2165-7904.1000172

16. Perdana F, Madanijah S, Ekayanti I. Pengembangan media edukasi gizi berbasis android dan website serta pengaruhnya terhadap perilaku tentang gizi seimbang siswa sekolah dasar. Jurnal Gizi dan Pangan. 2017;12(3):169-78. doi: 10.25182/ jgp.2017.12.3.169-178

17. Santoso AP, Baihaqi I, Persada SF. Pengaruh konten post instagram terhadap online engagement: studi kasus pada lima merek pakaian wanita. Jurnal Teknis ITS. 2017;6(1):A217-A221.

18. Thasim S, Syam A, Najamuddin U. Pengaruh edukasi gizi terhadap perubahan pengetahuan dan asupan zat gizi pada anak gizi lebih di SDN Sudirman I Makassar tahun 2013 [Skripsi]. Makassar; Universitas Hasanuddin Makassar: 2013.

19. Committee on Adolescents Health Care. Obesity in adolescents. Committee Opinion No. 714. American College of Obstetricians and Gynecologists. Obstet Gynecol 2017;130:e127-40.

20. Mirkarimi K, Mostafavi F, Eshghinia S, Vakili MA, OzouniDavaji RB, Aryaie M. Effect of motivational interviewing on a weight loss program based on the protection motivation theory. Iran Red Crescent Med J. 2015;17(6):e23492. doi: 10.5812/ircmj.23492v2

21. Waman AM. Teori dan pengukuran pengetahuan sikap dan perilaku manusia: dilengkapi contoh kuesioner. Yogyakarta: Wuha Media; 2011.

22. Kim S, Haines PS, Siega-riz AM, Popkin BM. The diet quality index international (DQI-I) provides an effective tool for cross-national comparison of diet quality as illustrated by China and the United States. J Nutr. 2003;133(11):3476-83. doi: 10.1093/jn/133.11.3476

23. Yustias PF, Aryana IK, Suyasa ING. Efektivitas penggunaan media cetak dan media elektronika dalam promosi kesehatan terhadap peningkatan pengetahuan dan perubahan sikap siswa SD. Jurnal Kesehatan Lingkungan. 2014;4(1):29-39.

24. Barnes RD, Ivezaj V, Martino S, Pittman BP, Paris M, Grilo CM. Examining motivational interviewing plus nutrition psychoeducation for weight loss in primary care. J Psychosom Res. 2018;104:101-7. doi: 10.1016/j.jpsychores.2017.11.013

25. Retraningrum G, Dieny FF. Kualitas diet dan aktivitas fisik pada remaja obesitas dan non obesitas. Journal of Nutrition College. 2015;4(4):469-79. doi: 10.14710/jnc.v4i4.10150

26. Swinburn BA, Caterson I, Seidell JC, James WPT. Diet, nutrition, and the prevention of excess weight gain and obesity. Public Health Nutr. 2004;7(1A):123-46. doi: 10.1079/ phn2003585

27. Dieny FF. Permasalahan gizi pada remaja putri. 1st ed. Yogyakarta: Graha Ilmu; 2014.

28. Shofia N, Sulchan M. Pengaruh konseling modifikasi gaya hidup terhadap asuoan serat,kadar glukosa darah puasa, dan kadar interleukin 18 (IL-18) pada remaja obesitas dengan sindrom metabolik. Journal of Nutrition College. 2015;4(3):243-51. doi: 10.14710/jnc.v4i3.10089

29. J Victor, Stevens, Glasgow RE, J Deborah, Toobert, Karanja $\mathrm{N}$, et al. One-year results from a brief, computer-assisted intervention to decrease consumption of fat and increase consumption of fruits and vegetables. Preventive Medicine. 2003;36(5):594-600. doi: 10.1016/s0091-7435(03)00019-7

30. Poll FA, Miraglia F, D'avila HF, Reuter CP, Mello ED. Impact of intervention on nutritional status, consumption of processed foods, and quality of life of adolescents with excess weight. J Pediatr (Rio J). 2020;96(5):621-9. doi: 10.1016/j. jped.2019.05.007

31. Dieny FF, Widyastuti N, Fitrianti DY. Sindrom metabolik pada remaja obes: prevalensi dan hubungannya dengan kualitas diet. Jurnal Gizi Klinik Indonesia. 2015;12(1):1-11. doi: 10.22146/ijen.22830

32. Hermina, Prihatini S. Gambaran konsumsi sayur dan buah penduduk indonesia dalam konteks gizi seimbang: analisis lanjut Survei Konsumsi Makanan Individu (SKMI) 2014. Buletin Penelitian Kesehatan. 2016;44(3):205-18. doi: 10.22435/bpk.v44i3.5505.205-218

33. Anggraeni NA, Sudiarti T. Faktor dominan konsumsi buah dan sayur pada remaja di SMPN 98 Jakarta. Indonesian Journal of Human Nutrition. 2018;5(1):18-32. doi: 10.21776/ ub.ijhn.2018.005.01.3

34. Green LW. Modifying and developing health behaviour. Annu Rev Public Health. 1984;5:215-36. doi: 10.1146/annurev. pu.05.050184.001243

35. Adriani M, Wirjatmadi B. Pengantar gizi masyarakat. Jakarta: Kencana; 2012.

36. Bundy C. Changing behaviour: using motivational interviewing techniques. J R Soc Med. 2004;97(44):43-7. 